\title{
(Mis)understanding strategy as a 'spectacular intervention': a phenomenological reflection on the strategy orientations underpinning school improvement in England
}

\begin{abstract}
The introduction of the 'National Strategies' for primary education in 1998, positioned 'strategy' as a powerful instrument for mobilising the school 'workforce' in England in the cause of continuous improvement. Government approaches to strategy formulation and enactment appear to reflect an instrumentalist orientation found in many mainstream strategic management publications. This paper reflects on how the strategic pursuit of quick, 'spectacular' gains may lead to the loss of ethics of care. Phenomenological insights into modes of being-in-the-world are drawn upon to suggest that a preoccupation with strategy and its accompanying 'toolkit' of targets, standards and inspections diminishes a deeper engagement with the meaning and purpose of education. Based on Heidegger's premise that understanding is at the core of being human, it is posited that the concern with 'spectacular' outputs is both superficial and potentially de-humanising. At the root of strategic thinking and the resulting forgetfulness of being is the Cartesian dogma and its dualistic (mis)understandings.
\end{abstract}

Keywords strategy, school improvement, ethics of care, understanding, Heidegger

\section{Introduction}

Education reform remains high on the agenda of policy makers in England and other countries around the world. A recurring theme in the global narratives of education reform is a pursuit of 'spectacular' examination results (Stronach 2010). School improvement strategies in England express an ambition to be 'worldclass', to raise the standards of pupil performance in national tests and outperform other countries in international comparisons, such as the Programme for International Student Assessment. The reliance on strategy as a panacea for a range of improvement issues started with the 'National Strategies', which were disseminated to primary schools by the New Labour governments between 1998 
and 2006. The strategies aimed at transforming education in England into a 'world-class' system (Department for Education and Skills 2004). Although the 'National Strategies' were ended following the general election in 2010, the Coalition government continues to encourage schools to develop their own improvement strategies (Department for Education 2010, 2011). Strategic approaches to school improvement originate in business management theory and practice, where the predominant orientation has been strategy conceptualised within the Cartesian paradigm of rationality, order and logic (Stacey 2010). Mainstream publications define strategy as a blueprint for change, based on clear organisational goals and aimed at increasing efficiency in the delivery of measurable outputs (Mintzberg and Quinn 1991). Strategising endows the leader/manager with the expertise of a knowing observer and power to align the followers to a vision of a better future state (Stacey 2007). Elements of classic Western theory of war strategy emphasise a 'spectacular intervention', the phalanx attack where victory is achieved by advancing in a single mass formation and crushing the opponent (Chia and Holt 2009).

This paper explores the origins and consequences of the strategic turn in education reform, by drawing on the conceptual and analytical resources of phenomenological sociology (Ferguson 2006). Phenomenological sociology is premised on a recognition that philosophical reflection enriches sociological descriptions of modern society, whereas sociological analysis 'revitalizes' philosophical enquiry through 'renewed encounter with reality' (ibid., p. 7). Bringing phenomenology and sociology together, argues Ferguson, enables the complexities of everyday life to be more fully understood, both in their current and historical context. In accordance with Ferguson's call for 'constructive intertextuality, or cross reading' (ibid., p. 13), the sociological analysis presented in this paper rests on a textual analysis of key school improvement authors: Barber (2008, 2011), Davies (2006, 2009) and Hill and Matthews (2010). In order to operationalise government strategies for school improvement, these authors draw on seminal mainstream publications on business strategy, such as Mintzberg and Quinn (1991), as their theoretical antecedent. My critique of the predominant view of strategy as a panacea for school improvement is supported by an alternative conceptualisation of strategy as a 'spectacular' illusion. 
A phenomenological 'cross reading' of the above literature locates strategy in the Cartesian universe, where the subject-object dualism creates a distinction between the detached, knowing subject and human or other resources to be calculated, manipulated and deployed for the aims of strategy (Chia and Holt 2009). In reflecting upon this instrumentalist approach to strategy, this paper draws on Heidegger's thinking pre-1940, particularly his explication of being presented in 'Being and time' (Heidegger 1927/1962) and refined in 'Building dwelling thinking' (Heidegger 1956/1975). Whilst explaining the meaning of 'being' (Sein), Heidegger points out that, paradoxically, being is both the 'most universal concept' and the 'darkest of all' (1962, pp. 22-23). Being is not a member of a class or genus and, consequently, cannot be described through categories applicable to objects. Questions about being are focused on what it means for human beings to exist. A related term, 'Dasein' (there-being), refers to humans as entities that are able to reflect on what it means to be (Wheeler 2011). At its innermost core, 'Dasein' is about being-in-the-world, a mode in which we encounter (other) entities in their being, rather than behold them as objects which are separate from us. Heidegger's ontology is thus in stark contrast with the Cartesian world, where being remains veiled behind the sophisticated conceptual apparatus pertaining to the properties of subjects-objects-world in such a way that they can be measured, manipulated, used or improved. By 'destroying' Descartes' 'cogito sum', Heidegger (1962) returns us to a remembrance of being and the source of being in care ('Sorge'). In Heidegger's world, strategy loses its properties of a 'spectacular intervention' and becomes imbued with the 'average everydayness' (ibid., p. 38) of a tool such as a hammer or a needle. This understanding of strategy avoids unduly elevating the strategy designer above strategy implementers. It also reveals manipulative relations engendered when the singular focus of calculative reasoning is on effectively matching means to predetermined ends (MacIntyre 1985). In the 'average everydayness' of being-inthe-world, the core purpose of education is disclosed as teaching children to hold themselves back from manipulating or utilising, as well as safeguarding children from being manipulated or utilised. 


\section{The strategic turn in education reform}

The deployment of strategic approaches to education reform in England led to a series of 'National Strategies' designed for the primary education sector by the New Labour (DfEE 1998, 1999; DfES 2003, 2004, 2006). The 'National Strategies' were designed as a 'spectacular intervention', or the phalanx attack, as implicit in the following account by Tony Blair's chief strategist, Professor Michael Barber:

...we went at this first phase with enormous energy and drove reform with great speed. It was a completely mission-driven agenda... Large-scale reform driven from the top down; designing all the materials at the national level and training everybody in a cascade out... (Mead 2006)

Barber's approach to the 'National Strategies' draws on the business strategy 'toolkit' of vision and mission, targets and inspections. For Barber, 'envisioning' the future (1996, p. 5) is accompanied by setting measurable targets and conducting inspections to 'check' teacher 'buy-in' (Mead 2006). His preoccupation with target-setting is rooted in a conviction that targets convert 'airy aspirations into specific measurable commitment' and 'deliver' school improvement (Barber 2011, p. xix). The upshot of the preoccupation with measurable targets is that the 'National Strategies' focused teachers and school leaders on raising standards in national tests, foreclosing a deeper reflection on their meaning. Post-2010, education reform in England was based on a redefinition of the education system as the 'school market' and invitation for private providers to take over 'underperforming' state schools (Hill and Matthews 2010, p. 104). Whilst school improvement strategy continues to present 'teachers and school leaders with 'urgent' and 'necessary' tasks to perform' (ibid., p. 103), questions about educational purpose and ethics of care remain unanswered or trivialised, as illustrated by the critique of researchers writing under the aegis of the National College for Teaching and Leadership (NCTL), Davies (2006; 2009) and Hill and Matthews (2010), presented later in this paper.

The loss of pedagogical meaning is brought to light in a number of sociological analyses. For example, for Stronach (2010, pp. 35-37), teaching 'to the global test', in pursuit of 'spectacular' outputs, turns morality into a 'defective 
conformity to standards'. Ball, Maguire and Braun (2012, p. 95) are concerned about the 'unreflexive ease' with which 'teachers move between... different forms of [education] policy' in order to enact improvement policies and strategies. Compliance with the government reform agenda creates a 'good' school, which values achievers and simultaneously, 'by omission', excludes students who are 'failing' (Ball et al. 2012, p. 128). Ball (2009) and Gunter (2012) unmask privatisation as the hidden agenda of education reform and a threat to education as a public good. Whilst these analyses illuminate the immediate social consequences of the strategic turn in education, this paper locates school improvement strategies in Cartesian worldview. Thus, my core concern is also related to the moral deficit of improvement strategies through which 'we render children into strange and silent objects which require of us only management, manipulation, and objective information and (ac)countability' (Jardine 1998, p. 7). By tracing the roots of the moral deficit to Cartesian thinking, a philosophical analysis reveals that such manipulative relations are a predominant mode of relating to others in advanced modernity (MacIntyre 1985). It is through an examination of Cartesian thinking that we become conscious of what Heidegger (1962) refers to as our forgetfulness of being. An awareness of being is made possible once the Cartesian 'cogito ergo sum' is 'phenomenologically destroyed' (ibid., p. 128) and this deconstruction of 'I think therefore I am' is discussed next.

\section{Awakening from the 'Cartesian nightmare' to the awareness of being}

In an attempt to free enquiry from unquestioned compliance with authority, Descartes resolved to doubt everything, from the impressions of his senses to the illusions of his dreams (Russell 1996). In his waking life, he found a firm basis for his philosophy in the 'cogito ergo sum' principle:

I resolved to assume that everything that ever entered into my mind was no more true than the illusions of my dreams. But immediately afterwards I noticed that whilst I thus wished to think all things false... 'I think therefore I am' was so certain and assured that all the most extravagant suppositions brought forward by the sceptics were incapable of shaking it... (Descartes 2005, p. 16) 
The Cartesian method led to great advances in the natural sciences, which flourished as a result of rigorous, systematic, highly analytical pursuit of universal laws about the reality 'out there'. However, not unlike many other philosophical efforts to explain the origins of the world and our experience of it, the Cartesian method has ended 'in formalism and the pursuit of technical sophistication' (Ferguson 2006, p. 5). In fact, Jardine (1998, pp. 8-9) contends that 'Descartes's dream' is 'slowly, perhaps inextricably, becoming a nightmare', because the process of knowledge growth has been accompanied by 'the tyranny of a subject able to contact anything outside of itself only within the methodological parameters of its own self-presence and self-security'. The Cartesian method seeks understanding in order to control events, at the same time disconnecting us from the world as we encounter it in our immediate, everyday experience:

We are silently living out Descartes's dream-turned-nightmare; as we sever our connections with the Earth, it ceases to be our abode and becomes a meaningless objective mechanism which is at the disposal of our whim and consumptive fantasies... It is under this shadow that we can speak... of providing life-management courses in high school and have come to slowly transform being a parent into parenting skills, being a teacher into teaching skills. (Jardine 1998, p. 9)

The Cartesian world is reified - full of 'things'. Descartes' definition of the 'World' as 'res extensa', a 'corporeal substance', leads to a distinction between 'things' ('objects'), the thinking subject ('ego cogito') and God (Heidegger 1962, p. 123). Understanding such world of objects is predicated on identifying and categorising the measurable properties of the substance ('res extensa'), in accordance with the scientific principles of mathematics and physics. Heidegger points out that the scientific method privileges the kind of judgment whereby our senses 'merely serve to announce the ways in which 'external' Things within-theworld are useful or harmful for human creatures' (ibid., p. 129). This, in turn, gives rise to dualistic distinctions between subject-object, utility value and harm, nature-spirit, mind-body, manager and staff, opponent and ally, spectator and actor. The Cartesian world is therefore a fitting environment for what the political scientist Colin Gray (1999, p. 354) refers to as the universal strategic experience arising from the basic human social condition of 'threat or use of politically 
motivated force'. Similarly, Bolman and Deal's (1991, p. 24) notion of managerial understanding places the subject and object in an oppositional relation:

The first step in managerial wisdom and artistry is to understand the nature of the beast - the situation - you are up against.

Descartes' doctrine of the substantiality of the 'world' was a precursor of the scientific method, which seeks knowledge of the measurable properties of entities and ignores their being:

...Descartes can hardly reach the Being of substance... Descartes has narrowed down the question of the world to that of Things of Nature... as those entities within-the-world which are proximally accessible. He has confirmed the opinion that to know an entity... is our only possible access to the primary Being of the entity which such knowledge reveals. (Heidegger 1962, p. 133)

Consequently, epistemology became the key preoccupation of philosophy, which further obscured ontological questions. Descartes...

made it impossible to lay bare any primordial ontological problematic of Dasein; this has inevitably obstructed his view of the phenomenon of the world, and has made it possible for the ontology of the 'world' to be compressed into that of certain entities withinthe-world. (ibid., p. 131)

The problem with the Cartesian rationality, therefore, is that it leads to a misunderstanding of being, which 'lies veiled in the concept of substantiality' (ibid., p. 128). Heidegger rejects Cartesian 'cogito sum' as the origin of philosophical and scientific enquiry, turning instead to ontological investigations and these lead him to the roots of human being in care, concern ('Sorge'). Care is for Heidegger not only 'primordial', closest to the essential nature of being; care is also a source of being:

...in care this entity [wo/man] has the source of its Being... the entity is not released from this source but is held fast, dominated through and through as long as this entity 'is in the world'. (ibid., p. 243)

Insights from Heidegger's $(1962 ; 1975)$ philosophy of being suggest that the disconnections created by 'strategic' thinking perpetuate the perception of the world as reified, full of objects and resources encountered as 'present-at-hand': to 
be manipulated, used and harnessed. Heidegger's explication of being reveals that the Cartesian subject-object dualism which orients us towards being as presenceat-hand is simply one of several modes in which we encounter the world. At its most 'primordial', closest to its essential nature, our being is about care, which is the source of our being. Understanding the meaning of being as care is of profound moral value, in contrast to the managerial 'wisdom and artistry' defined by Bolman and Deal (1991) as the understanding of the 'beast', the situation 'we are up against'. Heidegger reminds us that, because of 'throwness', our being thrown into the world, we rely on the world, we are being-in-the-world, not up against it as an entity that is potentially 'harmful' or threatening. The concept of strategy diminishes in significance; the essential nature of being as care means that 'strategy' does not exist in the 'primordial', ontological sense in Heidegger's World. Phenomenology, therefore, requires us to relearn to perceive the world as we encounter it in the immediate everyday experience of care and concern (Van Manen 1990). As long, however, as we look at the world through Descartes' eyes of a detached observer, we perpetuate the condition of incessant strife. It is to the understandings of strategy rooted in Cartesian thinking that we now turn.

\section{Mainstream (mis)understandings of strategy}

In the context of military conflict, strategy is defined as 'the use that is made of force and the threat of force for the ends of policy' (Gray 1999, p. 17). Based on the exercise of power with regard to a vision of what is considered to be desirable, strategy is thus a means to achieving instrumental ends. Strategic leaders exercise their authority to affect the behaviour of the followers by means of vision, policy, strategy, operations and tactics. According to Gray, what is fundamental and obvious in strategising, though often overlooked, is the human dimension to strategy, the ordinary people at the frontline who contribute either to victory or defeat. What sustains wars in modern times, he argues, by drawing on by the famous military theorist Clausewitz, is a combination of the human factor, chance and subordination to authority:

The master concept in Clausewitz's theory of war is not strategy; rather it is the 'remarkable trinity - composed of primordial 
violence, hatred, and enmity... the play of chance and probability... and [the] element of subordination, as an instrument of policy'.

(ibid., p. 28)

Whereas in the military context strategy is as old as humanity itself, in more recent times strategy has been utilised as instrumental in improving organisational output and gaining competitive advantage in the marketplace. Mainstream management literature constructs strategy as crucial to the growth of businesses and educational organisations, as well as providing a sense of purpose and meaning to their employees. In strategic management the 'spectacular intervention' is premised on following the chief strategist, a CEO (Chief Executive Officer) or an 'executive headteacher' (Hill and Matthews 2010), who mobilises and aligns the workers in the organisation to his/her vision of a better future. Underpinning these understandings of strategy are hierarchies which diminish the role of the people at the frontline of organisational improvement.

The strategic turn in education in England was endorsed by the creation in 2000 of the National College for School Leadership (NCSL, recently renamed as National College for Teaching and Leadership, NCTL). NCTL was tasked with developing a leadership cadre to drive the implementation of government reform (Gunter 2012). In accordance with the recommendation that school leaders are to be 'strategically driven' (NCSL 2001, p. 5; NCSL 2012), Brent Davies, a key NCTL researcher, promotes strategy as vital for sustained school improvement. According to Davies (2009), school leaders need to be 'strategically focused', with 'strategic thinking', 'strategic planning' and 'strategic conversations' at the core of their everyday practice. A strategic headteacher is presented by Davies (2006, p. 37) as a detached, expert observer 'looking at the school' and articulating a vision which enriches 'a school culture with values and beliefs for its strategic journey'. Unequal power relations between the leader and followers are constructed by Davies (2006, pp. 30-37 ) through references to leaders who 'harness the abilities of others' and engage in 'awakening the people' or 'aligning the people'. The strategic leader is a 'spectacular' individual, who holds the symbolic roles of: 'historian', 'anthropological sleuth', 'visionary', 'symbol', 'potter', 'poet', 'actor', 'healer'. By elevating him/her to this 'spectacular' position, Davies presents the strategic leader as a 'bureaucratic manager', 'therapist' and 'aesthete', all in one. According to MacIntryre (1985), these three 
characters shape the social relations of advanced modernity, presenting themselves as uncontested figures, whilst at the same time displacing truth with effectiveness. For example, the 'manager'...

treats ends as given, as outside his scope; his concern is with technique, with effectiveness in transforming raw materials into final products, unskilled labor into skilled labor, investment into profits. (ibid., p. 35)

These characters are also 'moral representatives', providing modern culture with its moral definitions (ibid., p. 32). Accordingly, strategy is presented by Davies (2006) as a means to moral ends. He defines a school's moral purpose as developed from 'strategically useful... basic beliefs' (2006, p. 35). The basic beliefs are to be:

- universal - applicable 'at every level of the school... every function... every location, with no exceptions';

- realistic - expressing 'attainable goals for continuous implementation';

- measurable - by identifying 'kinds of observable behaviours and standards';

- demonstrable - seen 'in action';

- consequential - 'if a school's basic beliefs have no impact on its decisionmaking, they are irrelevant'. (Davies 2006, p. 35)

The universal applicability of 'strategically useful' beliefs locates them in the Cartesian paradigm. The prescription for 'realistic', 'measurable' and 'demonstrable' beliefs frames them as 'SMART targets': specific, measurable, ambitious, realistic and time-limited (Barber 2008). The criterion of 'consequentiality' aligns a school's 'basic beliefs' with a utilitarian principle of 'the greatest usefulness for the greatest number of decisions'. Beliefs are promoted here as a leadership tool utilised for safeguarding compliance with a 'morally driven' school improvement, 'moral' being defined in terms of consistent performance against benchmarks (Davies 2006). The consequences of the superficial, utilitarian approaches to improvement framed as benchmarks and targets are presented by Jardine (1998, p. 7) thus:

Children are no longer our kin, our kind; teaching is no longer an act of "kindness" and generosity bespeaking a deeper connectedness with children. In the name of clarity, repeatability, accountability, such connections become severed in favour of pristine, "objective" surface articulations. 
The superficiality of such (mis)understandings of beliefs and 'moral' values is reflected in case studies of 'successfully' improving schools and their 'spectacular' leaders, designated as National Leaders of Education (NLEs). The NLEs have the expertise and skills to rapidly transform schools, as illustrated in a research report by Hill and Matthews (2010, pp. 33-34):

Since the start of the academic year, the executive headteacher and senior leaders have swiftly introduced and implemented a range of actions to tackle the key issues for improvement.

...these NLEs are taking the vision and values, teaching and learning models, behaviour management, operating systems and the wider leadership expertise of their schools and transplanting them into new contexts to sponsor and run new academies.

Promoting expertise and efficiency in implementing improvement as core qualities of the new cadre of 'executive headteachers' silences alternative educational aims, such as caring for the child. For example, New Labour's aspiration of 'better life chances' for children and young people which was presented as a core purpose of the 'National Strategies' (Beard 2000; DfES 2004) is mentioned only once in the 120 pages-long research report by Hill and Matthews (2010). When writing about improving the school system, these NCTL authors do not make any references to 'care', 'equality', 'justice', 'citizen/ship', or 'society'. In contrast, 'school improvement' and related words and phrases, such as 'sustaining improvement', 'improved', 'need to improve', 'notice to improve', 'improving', are used over 300 times, mainly in the context of 'performance', 'outcomes' and 'results', without an explicit statement of the purpose of improvement. School improvement strategy as a means to an end has thus become an end in itself.

Such obliteration of the distinction between means and ends is characteristic of what MacIntyre (1985) describes as the emotivist culture, embodied by modern-day experts: the 'bureaucratic manager', the 'aesthete' and the 'therapist'. Although not written in the phenomenological tradition, MacIntyre's analysis complements Heideggerian exposition of the manipulative mode of being. On MacIntyre's analysis, the conflation of means and ends characteristic of the emotivist culture provides grounds for manipulation of 
organisations and individual people involved in education for the ends of the dominant managerial elite. The roots of emotivism go back to the Enlightenment's rejection of a teleological view of human nature. The rejection undermined the status of traditional moral judgments, providing conditions for the rise of the 19th century utalitarianism and its 'decline into emotivism' in the 20th century. Without telos, a 'true end' which fulfills the essential human nature, moral precepts lose their traditional categorical status, giving way to 'scientific facts', for example pertaining to managerial effectiveness. However, claims to managerial effectiveness lack sufficient rational justification and, consequently, under the guise of morality and science, emotivism articulates arbitrary preferences and 'fictions' of social control. The manipulative mode in our culture...

is not and cannot be accompanied by very much actual success in manipulation. I do not of course mean that the activities of purported experts do not have effects and that we do not suffer from those effects and suffer gravely... Our social order is in a very literal sense out of our, and indeed anyone's, control. (ibid., p. 124)

To return to Heidegger's explication of the totality of Dasein's involvements in the world, the manipulative social relations of the advanced modernity are one in a number of different modes of being. More importantly, '[s]o far as Dasein is at all, it has Being-with-one-another as its kind of Being' (1962, p. 163). The main mode of Dasein's encounters with others is nonmanipulative, rooted in understanding other entities as possibilities. Such encounters are "accomplished' by 'care"' (ibid., p. 243). In the light of MacIntyre's analysis of managerial 'fictions' and Heidegger's articulation of the possibilities for non-manipulative relations, the notions of strategy as instrumental in delivering 'spectacular' interventions may be considered as misleading or illusory. Sociological critiques of such conceptualisations provide the focus of the following section.

\section{From strategy as a 'spectacular' illusion to 'strategic blandness'}

Alternative conceptualisations of strategy and strategic leadership aim to ‘improve' strategy by addressing its limitations (Mintzberg 1994), or deconstruct 
the very notion of strategy (Stacey 2007, 2010; Chia and Holt 2009; Phillips and Dar 2009). For example, Mintzberg (1994) recommends moving away from strategic choice and long term planning to the notion of strategic management as a process of learning. Mintzberg emphasizes the distinction between the intended and realised strategy, thereby shifting managers' role from formulating preconceived deliberate strategies to managing the process of strategic learning, which may allow for novel strategies to emerge. This perspective questions the separation of the planned and realized strategy as it unfolds over time. Writing under the aegis of Critical Management Studies (CMS), Phillips and Dar (2009) provide an analysis of strategy viewed at different levels: strategy as ideology, as discourse, as political economy and as practice. Strategy framed as ideology reveals the hidden agenda of strategy literature to serve the interests of practising managers and naturalise the status quo. At the level of discourse, strategic language legitimises rationality, objectification of people and the environment, simultaneously silencing alternatives. As political economy, strategy is crucial in deploying economic resources. Strategy as practice focuses on how strategy is performed and lived out through everyday interactions of people working in organisations. Phillips and Dar (2009: 429) also express concern about the impact of strategic thinking on 'large numbers of people in and around organizations, their lives, and ultimately the choices available to them'.

A similar approach to strategy is presented by Chia and Holt (2009) who criticise mainstream strategic management textbooks for their disconnection from practice. Accordingly, Chia and Holt (2009, p. ix) investigate the emergent nature of strategy as it develops at the level of 'local actions and adaptations without the oversight or pre-authored design of 'big' strategists'. Their exploration of the epistemological underpinnings of the typical notion of strategy-making as deliberate, planned and purposeful leads them to some important conclusions. Firstly, deliberate strategic planning is often both limited and self-defeating:

Ambitious strategic plans, the 'big picture' approach that seeks a lasting solution or competitive advantage through large-scale transformations, often end up undermining their own potential effectiveness because they overlook the fine details of everyday happenings at 'ground zero' level. (ibid., p. 18) 
Apart from ignoring the implementers, strategies are often an expression of strategy-makers' ambition to realize their goals in a 'spectacular manner', in tune with the Western 'obsession with the dramatic and the spectacular' (ibid., p. 187). 'Spectacular intervention' is a mode of engagement whereby leaders orient themselves towards directly confronting and overcoming obstacles and mobilising all available resources for one decisive attack. An expectation of a quick win often turns out to be an illusion; it ignores both the 'gritty' reality of everyday life and the possibility of losing the battle. Strategic leaders' deployment of people, assets and other resources 'around the 'territory', as if on a chessboard' (ibid., p. 21), is, for Chia and Holt, symptomatic of our underlying tendency to perceive ourselves as autonomous individuals, detached, objective observers. In criticising this mentality the authors juxtapose the 'silent efficacy of indirect action' with the forcefulness, superficiality and externality of strategy devised and executed as a direct intervention. The authors recommend 'strategic blandness', 'a strategy-less strategy', which is about relinquishing positions, plans and objectives and being open to the possibilities of change whilst being under way, whilst simply engaging in our everyday practice, for '[w]e only know as we go' (ibid., p. 187).

In summary, these critiques emphasise that mainstream strategic thinking compels us to mobilise and live in a state of perpetual strife. The focus on 'futures thinking', articulated as strategic vision, singular, precludes alternative perspectives. It cancels the past and postpones the present for the sake of an illusory, uniform, standardised future, employed as a tool for capturing the imagination, effort and commitment of people who could pursue different life goals, in their own, diverse ways. Strategic plans reify everyday reality into targets and objectify both the natural and human world as strategic resources. In education, strategising encourages reductive approaches to school improvement constructed as a battle for better standards. This results in an impoverished moral landscape, in which we struggle to build a 'spectacular' edifice of school improvement, but do not dwell. It is to the distinction between building and dwelling (Heidegger 1975) that the paper will now turn. 


\section{Thinking for the sake of $d w e l l i n g$}

The distinction between 'building' and 'dwelling' was a result of Heidegger's reformulation of his original question about the meaning of being as: 'How does Being essentially unfold?' (Wheeler 2011). An etymological investigation of the verb 'to dwell' reveals the common root of 'dwell' ('bauen') originally meaning both 'to build' and 'to dwell' and sharing the same root with 'to be' ('bin'). This led Heidegger (1975) to reconnect being-dwelling-and-building and a reflection that it is dwelling, rather than building, which is essential for human being to unfold. Dwelling involves sparing, preserving and a kindly concern for the world in which we dwell. Heidegger points out the limitations of thinking of building as merely erecting buildings in order to inhabit them. He argues instead for elevating dwelling to 'the fullness of its nature', which can be accomplished when we 'build out of dwelling, and think for the sake of dwelling' (ibid., p. 161).

The implications of this distinction for the discussions presented in this paper are two-fold. Firstly, in relation to strategy and strategic leadership, the essence of being as dwelling is about recognising that both the world and entities which are in the world exist as things-in-themselves (Heidegger 1962) and that we rely upon both. As Chia and Holt (2009) emphasise, the $d$ welling mode requires us to change our approach to strategy from confronting the environment as a stock of human and material resources, controlled, deployed and utilised for building competitive advantage to encountering and respecting the world and its resources as something we rely upon.

Secondly, in relation to educational meaning and purpose, the mode encouraged by the 'National Strategies' and strategic leadership has been that of building. Building success, constructing school vision and mission statements, erecting the edifice of school improvement. It has encouraged school leaders and teachers to think in terms of abstract measures of attainment and progress in learning, targets, standardised objectives. This draws practitioners away from dwelling with children in their everydayness, in their being, and promotes instead encounters with children as de-humanised entities, objects to be categorised, stretched, boosted through intervention classes, primed for examinations, or improved in other manipulative ways. An understanding of $d$ welling with children would release practitioners from a single-minded preoccupation with projected 
attainment targets. The concern about children's academic achievement cannot be discarded, but needs to be considered as one of many modes of being-in-theworld. In the building mode, it may be acceptable to say that 'vision creates meaning in people's lives' and 'the right vision' is about excellent performance standards (Davies 2006, p. 28). In the dwelling mode, however, the moral imperative would be to teach pupils 'to think for the sake of dwelling', which is about 'holding-oneself-back from any manipulation or utilization' (Heidegger 1962, p. 89). Heidegger's appeal to think for the sake of $d w e l l i n g$ could be read as the telos, the ultimate purpose of both human existence and education. It could, therefore, provide what MacIntyre (1985) refers to as a crucial element in a rational moral scheme which avoids emotivism.

\section{'Strategy' in Heidegger's world?}

Heidegger's approach to 'strategy' could be developed in two different ways. Firstly, based on the notion of strategy as a plan, or 'tool' for organisational improvement, strategy could be approached in its being 'ready-to-hand'. Readiness-to-hand is a kind of being that equipment possesses. Strategy as readyto-hand loses its properties of a 'spectacular intervention' by top management and becomes imbued with the average everydayness of a hammer, or a needle, or any other tool meant to be used with 'circumspection', with care, because the benefits of the work produced with tools are to be authentically shared with others:

that with which we concern ourselves primarily is the work - that which is to be produced at the time... along with the work, we encounter not only entities ready-to-hand but also entities with Dasein's kind of Being... and together with these we encounter the world in which... users live, which is at the same time ours. (Heidegger 1962, pp. 100-101)

It is care, or circumspection, Gibbs (2010) explains, that enables educators to engage in practice in ways which are concerned about the totality of praxis. This totality transcends the focus on the goals or aims of our work to include professional choices which are made in the 'holistic context of relations', where 'students appear as students, not as delinquents to be controlled' (ibid., p. 276). 
Secondly, following from Heidegger's preoccupation with ontological enquiry and the conception of philosophy as ontology, rather than epistemology (Rorty 1979), the science of strategic leadership is worthwhile to the extent to which it commits itself to fundamental ontological questions. Heidegger (1962, p. 29) argues for research whose...

real progress comes not so much from collecting results and storing them away in 'manuals' as from inquiring into the ways in which each particular area is basically constituted... The real 'movement' of the sciences takes place when their basic concepts undergo a more or less radical revision which is transparent to itself. The level which a science has reached is determined by how far it is capable of a crisis in its basic concepts.

One of the fallacies of the scientific management is its basic notion of the strategic manager viewed as a detached, expert observer, 'looking at' an organisation as if from the outside and, paradoxically, simultaneously participating in the work of the organisation (Stacey 2007). Other basic concepts of strategic leadership, such as standards, targets and efficient performance can also be interpreted as blocking the real 'movement' in strategic thinking. That is unless they undergo a 'radical revision' and are examined with a rigour that will prevent them from becoming the 'most universal and the emptiest of concepts' (Heidegger 1962, p. 21).

'Targets' is one such example of a universal, empty concept. When targets were introduced through the 'National Literacy Strategy', research on their impact on teaching and learning was limited and the only justification for introducing target-setting into primary education was 'its long-standing use in industrial management and its increasing use in improving public services' (Beard 2000, p. 10). Targets in industry originate in Frederic Taylor's (1911) scientific management. Taylor aspired to improving efficiency through 'best' management, which rests 'upon clearly defined laws, rules and principles' and is 'applicable to all kinds of human activities' (ibid., p. 3). The rules developed by the scientific manager are based on a systematic observation of workers, precise timing, recording and calculation of their performance. Having given examples of how the scientific manager can improve the efficiency of handling pig-iron, Taylor asserts the managerial power and superiority and denies the worker what is essential for being, understanding: 
This work is so crude and elementary in its nature that... it would be possible to train an intelligent gorilla so as to become a more efficient pig-iron handler than any man can be. Yet... the science of handling pig-iron is so great and amounts to so much that it is impossible for the man who is best suited to this type of work to understand the principles of this science, or even to work in accordance with these principles without the aid of a man better educated than he is. (ibid., p. 30)

Taylor's industrial management is an example of what MacIntyre (1985) points out to be both a 'fiction' of managerial effectiveness and a cause of potential 'suffering' engendered though manipulative managerial activities. Workers have become objectified by Taylor as workforce, whilst the manager plays the 'spectacular' role of the knowing subject, observing, assessing, setting targets.

Denying the working man an understanding of the tasks which he engages with in his 'average everydayness' creates an illustrious meaning-making role for the manager. This hierarchy of roles, which privileges dominant managerial elites, recurs in contemporary notions of school leadership, where strategic leaders' vision 'creates meaning in people's lives' (Davies 2006, p. 28) and teachers are presented as entirely dependent on the headteachers:

[before the arrival of the headteacher...] The school had been a rudderless ship, working really hard without a sense of direction and not getting anywhere. (Hill and Matthews 2010, p. 53)

Implicit in such claims is a message that people's lives would be meaningless without the vision or direction of the 'spectacular' leader and that meaning can be given to, or imposed on, someone. Manipulative relations are also promoted through the use of skills which leaders need for 'doing' with the teachers what they 'do with a child':

The skills incorporate analysis, diagnosis and synthesis, exactly the same as assessing a student's progress. What you do with a child, you do with an adult. (Hill and Matthews 2010, p. 29)

Thrown into Heidegger's World, 'spectacular' leaders lose their power to impose or create meanings for others. Relinquishing the methodological individualism of Cartesian 'cogito sum' opens up the possibility of coming to knowledge collectively, through engagement with others. As methodological individualism gives way to methodological collectivism (Chia and Holt 2009), the 
strategic leader loses the authority of a knowing spectator, manipulating objects and human resources for strategic gains. Knowledge becomes created through a dialogic-dialectic process of articulating understandings in the presence of others. Educational practice does not need to be made meaningful by an inspector, checking the implementation of strategies, or another expert observing the classroom from a privileged vantage point. This is because...

something is already at play, and the living character of this setting is not waiting upon the inquirer for some beneficent bestowal of meaning... Understanding this situation is something everyone in this classroom is already involved in, teacher and children alike. (Jardine 1998, p. 23)

Heidegger's (1962) 'destruction' of the 'cogito sum' opens up another possibility, for the totality of being-in-the-world to be discovered. This includes different modes of engagement, associated with presence-at-hand, readiness-tohand and being-in-the-world. Paradoxically, therefore, by giving up our privileged, superior position as the Cartesian subjects and submitting ourselves to the world, we gain an opportunity for the discovery of the full richness of existence: 'Dasein, in so far as it is, has always submitted itself already to a 'world' which it encounters, and this submission belongs essentially to its Being' (pp. 120-121).

\section{Conclusion}

With Heidegger's explication of being we are thrown into a world which announces itself to us differently, unlike the Cartesian world. Heidegger's world is unlike Gray's (1999, p. 354) world, where the fundamental human condition of struggle for power makes strategy omnipresent and 'eternal'. It is unlike Bolman and Deal's (1991) world, where understanding places the knowing subject and the object to be understood in an oppositional relation. It is unlike the wish to dominate over natural and human resources for the sake of benefitting the powerful few. The superficiality of 'spectacular' interventions creates an education system dominated by targets, standards and strategies which reduce the meaning of children's learning to levels of attainment and promote the notion of 
education as a perpetual strife for improvement, defined through the same narrow measures.

Heidegger (1962) reminds us that the history of modernity originates in Descartes' 'cogito ergo sum', 'I think therefore I am'. In 'destroying' the 'cogito sum', Heidegger averts the Cartesian reduction of human consciousness to rationality and disturbs our self-perception of disconnected, detached spectators. What he returns us to is ontologically worlds apart from the Cartesian atomistic, fragmented universe. It is a world where we are being-in-the-world-with-others. Education in this world is not about Cartesian thinking, instrumental in asserting our existence. It is about thinking for the sake of $d w e l l i n g$. In a way, Heidegger does not 'destroy' Cartesian 'cogito sum' as much as imbues both thinking and being with understanding, thus disclosing that ' $[\mathrm{u}]$ nderstanding is the existential Being of Dasein's own potentiality-for-Being' (ibid., p. 184). Cartesian 'I think therefore I am' is disclosed as: 'I am, therefore I think and understand and make my being visible as care'.

\section{Acknowledgements}

The author wishes to thank the anonymous reviewers of a previous draft of this paper for their very insightful and helpful comments.

\section{References}

Ball, S. J. (2009). Privatising education, privatising education policy, privatising educational research: Network governance and the 'competition state'. Journal of Education Policy, 24(1), 83-99.

Ball, S. J., Maguire, M., \& Braun, A. (2012). How schools do policy: Policy enactments in secondary schools. London and New York: Routledge.

Barber, M. (2008). Instruction to deliver: Fighting to transform Britain's public services. London: Methuen Pub. Ltd.

Barber, M. (2011). Deliverology 101: A field guide for educational leaders. Thousand Oaks: Corwin.

Beard, R. (2000). The National Literacy Strategy: Review of research and other related evidence. Sudbury: DfEE Publications.

Bolman, L. G., \& Deal, T. E. (1991). Reframing organisations: Artistry, choice, and leadership. San Francisco: Jossey-Bass Publishers.

Chia, C. H., \& Holt, R. (2009). Strategy without design: The silent efficacy of indirect action. Cambridge: Cambridge University Press.

Davies, B. (2006). Leading the strategically focused school: Success \& sustainability. London: Paul Chapman.

Davies, B. (2009). The essentials of school leadership, 2nd edn. London: Sage Publications.

Department for Education (DfE) (2010). The importance of teaching: The schools White Paper 2010. Available at: www.ictliteracy. info/rf.pdf/Schools-WhitePaper2010.pdf. Accessed 15 March 2012. 
Department for Education (DfE) (2011). The National Strategies 1997-2011: A brief summary of the impact and effectiveness of the National Strategies. http://webarchive.nationalarchives.gov.uk/20110809101133/http://nsonline.org.u k/node/512121?uc=force_uj. Accessed 6 August 2013.

Department for Education and Employment (DfEE) (1998). The National Literacy Strategy: Framework for teaching. London: DfEE.

Department for Education and Employment (DfEE) (1999). The National Numeracy Strategy: Framework for teaching mathematics. London: DfEE.

Department for Education and Skills (DfES) (2003). Excellence and enjoyment: a strategy for primary schools. London: DfES Publications.

Department for Education and Skills (DfES) (2004). Five year strategy for children and learners. Norwich: The Stationery Office.

Department for Education and Skills (DfES) (2006). Primary National Strategy: Primary framework for literacy and mathematics. Norwich: Crown Copyright.

Descartes, R. (2005). Discourse on method and meditations on first philosophy (E.S. Haldane, Trans.). Stilwell: Digireads.com Publishing.

Ferguson, H. (2006). Phenomenological sociology: Insight and experience in modern society. London: Sage Publications.

Gibbs, P. (2010). A Heideggerian phenomenology approach to higher education as workplace: A consideration of academic professionalism. Studies in Philosophy and Education, 29(3), 275-285.

Gray, C. S. (1999). Modern strategy. Oxford: Oxford University Press.

Gunter, H. M. (2012). Leadership and the reform of education. Bristol: The Policy Press.

Harris, S. (2007). The governance of education: How neo-liberalism is transforming policy and practice. London: Continuum.

Heidegger, M. (1962). Being and time (J. Macquarrie, \& E. Robinson, Trans.). Malden: Blackwell Publishing.

Heidegger, M. (1975). Building dwelling thinking. In Poetry, language, thought (A. Hofstadter, Trans.) (pp. 141-161). New York: Harper and Row Publishers.

Hill, R., \& Matthews, P. (2010). Schools leading schools II: The growing impact of National Leaders of Education. National College Publishing.

Jardine, D. W. (1998). To dwell with a boundless heart: Essays in curriculum theory, hermeneutics, and ecological imagination. New York: Peter Lang.

MacIntyre, A. (1985). After virtue: A study in moral theory, 2nd edn. London: Bloomsbury.

Mead, S. (2006). Education reform lessons from England: An interview with Sir Michael Barber. http://www.educationsector.org/publications/education-reform-lessonsengland. Accessed 6 September 2012.

Mintzberg, H. (1994). The rise and fall of strategic planning. Hemel Hempstead: Prentice Hall.

Mintzberg, H., \& Quinn, J. (1991). The strategy process: Context, contexts, cases. Englewood Cliffs: Prentice-Hall, Inc.

National College for School Leadership (NCSL) (2001). 'Think tank' report to governing council: Nottingham: NCSL.

National College for School Leadership (NCSL) (2012). System leadership prospectus. $\mathrm{http}: / / \mathrm{www}$. education.gov.uk/nationalcollege/docinfo?id=176721\&filename=syst em-leadership-prospectus.pdf. Accessed 27 August 2012.

Philips, N., \& Dar, S. (2009). Strategy. In M. Alvesson, T. Bridgman, \& H. Willmott (Eds.) The Oxford handbook of Critical Management Studies. Oxford: Oxford University Press.

Rorty, R. (1979). Philosophy and the mirror of nature (Princeton, Princeton University Press).

Russell, B. (1996). History of western philosophy. Bungay, Suffolk: The Bertrand Russell Peace Foundation Ltd. 
Stacey, R. D. (2007). Strategic management and organisational dynamics: The challenge of complexity to ways of thinking about organisations, 5th edn. Harlow: Pearson Education Limited.

Stacey, R. D. (2010). Complexity and organisational reality: Uncertainty and the need to rethink management after the collapse of investment capitalism, 2 nd edn. London: Routledge.

Stronach, I. (2010). Globalizing education, educating the local: How method made us mad. London and New York: Routledge.

Taylor, F. W. (1911). The principles of scientific management. ForgottenBooks.org.

Wheeler, M. (2011). Martin Heidegger. In Stanford Encyclopedia of Philosophy. http://plato.stanford.edu/entries/heidegger/. Accessed 31 July 2013.

Van Manen, M. (1990). Researching lived experience: Human science for an action sensitive pedagogy. New York: Suny. 